\title{
ACID-BASE STATUS OF ARTERIAL AND FEMORAL-VENOUS BLOOD DURING AND AFTER INTENSE CYCLE EXERCISE
}

\author{
J. I. Medbø ${ }^{1}$, H. Noddeland ${ }^{2}$, S. Hanem ${ }^{2}$ \\ ${ }^{1}$ National Institute of Occupational Health, Oslo, Norway \\ ${ }^{2}$ Department of Anaestesia, National Hospital, Oslo, Norway.
}

\begin{abstract}
Intense exercise depends on energy from both aerobic and anaerobic processes. These processes produce $\mathrm{CO}_{2}$ and lactate, respectively, and both metabolites affect blood's acid-base status. To examine how the acid-base status of arterial and femoral-venous blood is affected and regulated, seven healthy young men cycled for $2 \mathrm{~min}$ at constant power to exhaustion. Blood samples were drawn from indwelling catheters in the femoral artery and vein during exercise and for $1 \mathrm{~h}$ after, and the samples were analysed for lactate ( $\left.\mathrm{La}^{-}\right)$, acid-base parameters, and plasma electrolytes $\left(\mathrm{Na}^{+}, \mathrm{K}^{+}, \mathrm{Cl}^{-}, \mathrm{La}^{-}, \mathrm{HCO}_{3}^{-}\right)$. The chloride concentration in red blood cells $\left(c \mathrm{Cl}_{\mathrm{RBC}}\right)$ was also determined to quantify the chloride shift. Arterial (femoral-venous, fv, mean values) blood lactate concentration rose to $13.8 \mathrm{mmol} \mathrm{L}^{-1}$ (fv 15.7), $\mathrm{pH}$ fell to 7.18 (fv 7.00), $p \mathrm{CO}_{2}$ changed to $41 \mathrm{hPa}$ (fv 114), and blood bicarbonate concentration was more than halved after exercise. $c \mathrm{Cl}_{\mathrm{RBC}}$ rose by 5 (a) and $8 \mathrm{mmol} \mathrm{L}^{-1}$ blood (fv) during exercise. $p \mathrm{CO}_{2}$ and $\mathrm{pH}$ fell linearly by the lactate concentration. Consequently, blood bicarbonate concentration fell by $81 \%$ of the increase in blood lactate concentration, while blood base deficit rose $30 \%$ more than lactate did. Bicarbonate thus neutralised $62 \%$ of the total acid load. $c \mathrm{Cl}_{\mathrm{RBC}}$ rose in proportion to the amount of hydrogen ions buffered by haemoglobin, and chloride shift amounted to $31 \%$ of the total acid load. $\mathrm{pH}$ was lower and $p \mathrm{CO}_{2}$ and bicarbonate concentration were higher in femoral-venous than in arterial blood with the same lactate
\end{abstract}


concentrations. The relationship between base deficit and blood lactate concentration did not differ between arterial and femoral-venous blood. In conclusion, after intense exercise $\mathrm{pH}$ falls more in femoralvenous than in arterial blood because of a lack of respiratory compensation of the metabolic acidosis.

Key words: acid-base balance, anion gap, arterio-venous difference, blood, buffering, chloride, chloride shift, electrolytes, exercise, lactate, $\mathrm{pH}$, plasma.

\section{INTRODUCTION}

Intense exercise depends on anaerobic energy release, and breakdown of glycogen to lactate in the working muscles is quantitatively the most important anaerobic process [29]. Part of the lactic acid produced is released to the blood, thus reducing blood $\mathrm{pH}$ and altering its acidbase status [4, 24, 27, 33, 36, 43]. If exercise lasts for more than a few seconds, there is in addition a large aerobic energy release that leads to production of $\mathrm{CO}_{2}$ that again may lead to a respiratory acidosis of venous blood. The blood may also receive hydrogen ions by a process independent of release of lactate or $\mathrm{CO}_{2}$ from muscle to blood [2], possibly by a $\mathrm{Na}^{+}-\mathrm{H}^{+}$exchange [24]. Each process contributes to acidification of the blood and thus to a drop in blood $\mathrm{pH}$.

The relationship between the amount of lactic acid added to arterial blood and its acid-base status has been examined in several studies $[4,27,33,36]$. It is thus well established that not only $\mathrm{pH}$ but also the $\mathrm{CO}_{2}$-pressure $\left(p \mathrm{CO}_{2}\right)$ of arterial blood falls by the lactate concentration, meaning that there is a respiratory compensation for the metabolic acidosis introduced by lactate production. Venous blood may act as a closed compartment unable to reduce its $p \mathrm{CO}_{2}$ and thereby buffer acids by bicarbonate. A raised $p \mathrm{CO}_{2}$ will expectedly reduce the $\mathrm{pH}$ of venous blood considerably below that of arterial blood [16]; femoral-venous $\mathrm{pCO}_{2}$ may double during strenuous exercise, reducing $\mathrm{pH}$ further by 0.2 below that of arterial blood [37].Further differences in the acid-base status between venous and arterial blood have apparently not been studied.

Acids added to the blood can be neutralised by bicarbonate as well be buffered as by several nonbicarbonate buffers where haemoglobin and plasma proteins are quantitatively the most important ones. The 
contribution from each component in relation to intense, short-lasting, anaerobic types of exercise is not well known. Moreover, red blood cells can exchange bicarbonate with plasma chloride by the so called chloride shift mechanism [42]. The process is very fast, taking less than one second for equilibration [19]. However, the extent of this process in relation to high-intensity, anaerobic types of exercise has only been studied in arterialised blood [3], and possible differences between arterial and venous blood is therefore not known.

As $\mathrm{pH}$ falls, the net negative charge on plasma proteins is reduced, and anion gap of plasma would expectedly fall too. However, it has been suggested that anion gap may increase after intense exercise [27]. If so, other, unmeasured ions may perhaps appear in plasma, but this possibility has not been examined. On the other hand, our former study did not distinguished between concentrations of lactate and bicarbonate in plasma and in whole blood [27]. These ions are not evenly distributed in plasma and red blood cells, and that may have influenced conclusions drawn.

To examine changes in the acid-base status of blood further, healthy young men cycle for $2 \mathrm{~min}$ to exhaustion since this duration leads to a maximum anaerobic energy release [26, 29]. Blood samples were drawn from catheters in the femoral artery and vein during the exercise and at intervals for $1 \mathrm{~h}$ after. The samples have been analysed for lactate, acid-base parameters, and plasma electrolytes and the acidbase status of blood as well as red blood cell chloride concentration have been calculated.

\section{MATERIALS AND METHODS}

\section{Subjects}

Seven healthy male students at the Norwegian Police Academy volunteered to serve as subjects in this study after being given oral and written information about the experimental procedures and possible risks. The subjects were $25 \pm 2 \mathrm{yr}$ old (mean $\pm \mathrm{SD}$ ), $1.85 \pm 0.04 \mathrm{~m}$ tall, weighed $81 \pm 4 \mathrm{~kg}$, and their maximal $\mathrm{O}_{2}$ uptake was $39 \pm 2 \mu \mathrm{mol} \mathrm{kg}^{-1} \mathrm{~s}^{-1}\left(53 \pm 3 \mathrm{ml}_{\mathrm{STPD}} \mathrm{min}^{-1} \mathrm{~kg}^{-1}\right)$. The experiments were approved by The Ethics Committee of Health Region 1 in Norway. 


\section{Procedures}

All exercise was carried out at a Krogh-type cycle ergometer [20] at a constant pedalling frequency of $1.5 \mathrm{~Hz}$. The maximal $\mathrm{O}_{2}$ uptake and the highest cycle power that could be kept for 2 min were determined for each subject during pretests the last weeks before the experiments.

Each subject arrived at the laboratory in the morning after an overnight fast. Catheters were inserted into the femoral artery and vein. Further details on the catherisation procedures and the experiments have been given in more detail elsewhere [24], see their Figure 1). In short, the subject warmed up for $15 \mathrm{~min}$ at a power corresponding to $\approx 50 \%$ of his maximal $\mathrm{O}_{2}$ uptake. After a 10 min rest he cycled at a constant power established during the pretests for $\approx 2$ min to exhaustion. Blood samples from the femoral artery and vein were drawn in parallel in $5 \mathrm{ml}$ syringes before the exercise, after 30 , 60 and $90 \mathrm{~s}$ of exercise, and at $30 \mathrm{~s}, 1,3,6,10,15,20,30,45$, and $60 \mathrm{~min}$ after the exhausting bout. The blood samples were handled as described elsewhere [24] to allow measurement of haematocrit (Hct), blood lactate $(\mathrm{La})$ and haemoglobin $(\mathrm{Hb})$ concentrations, blood acidbase parameters $\left(\mathrm{pH}, p \mathrm{CO}_{2}, p \mathrm{O}_{2}, s \mathrm{O}_{2}\right)$, concentration of plasma electrolytes $\left(\mathrm{Na}^{+}, \mathrm{K}^{+}, \mathrm{Cl}^{-}, \mathrm{La}^{-}, \mathrm{HCO}_{3}{ }^{-}\right)$, and plasma albumin, and proteins.

\section{Analyses}

Maximal $\mathrm{O}_{2}$ uptake was established by the levelling-off criterion of Taylor et al. [40] using a discontinuous protocol of stepwise increases of cycle power, measuring the $\mathrm{O}_{2}$ uptake during the last $30 \mathrm{~s}$ of a 3 min exercise bout at constant power. The expired volume was measured in a wet Tissot-type spirometer [41], and fractions of $\mathrm{CO}_{2}$ and $\mathrm{O}_{2}$ in the expired air was measured by analysers from Applied Electrochemistry Instruments (Pittsburgh, PA, USA).

Blood and plasma parameters were measured as described elsewhere [24, 25]. In short, the lactate concentration in plasma and whole blood was measured by enzymatic photofluorometry according to Passoneau and Lowry [34]. Blood $\mathrm{pH}, p \mathrm{CO}_{2}$, and $p \mathrm{O}_{2}$ were measured on an IL 1312 blood gas manager (Instrumentation laboratory, Milan, Italy), while blood oxygen saturation $\left(s \mathrm{O}_{2}\right)$ was measured on an OSM 2 hemoximeter (Radiometer, Copenhagen, Denmark). Blood haemoglobin concentration $(\mathrm{cHb})$ was measured by a hemiglobincyanide method of Baxter Dade AG (Düdingen, Switzerland). The 
values are reported as concentrations in $\mathrm{mmol} \mathrm{L}^{-1}$ of blood using a molecular mass of haemoglobin of $16.114 \mathrm{kDa}$. Blood haematocrit (Hct) was measured on blood samples in heparinised capillary test tubes centrifuged for more than $3 \mathrm{~min}$ at more than $15000 \mathrm{~g}$ $\left(>1.5 \cdot 10^{5} \mathrm{~m} \mathrm{~s}^{-2}\right.$ ) on a Cellokrit 2 centrifuge (AB Lars Ljungberg, Stockholm, Sweden), thus giving a fraction of trapped plasma of $\approx 0.02$ between the red blood cells $[10,11]$.

Plasma sodium, potassium, and chloride concentrations were measured on a Microlyte ion selective analyser (Kone corporation, Espoo, Finland). Plasma albumin concentration was measured by procedure 631 of Sigma Diagnostics (St. Louis, MO, USA) where albumin binds to bromcreosol green. The concentration of the product formed was measured in a spectrophotometer at $477 \mathrm{THz}(628 \mathrm{~nm})$ and expressed in SI-units using a molecular mass of albumin of $66.5 \mathrm{kDa}$ [31]. The protein concentration was measured by the DC Protein assay method of Biorad laboratories (Hercules, CA, USA) using the two-step alkaline copper tartrate and folin reaction. The concentration of the product formed was measured in a spectrophotometer at $400 \mathrm{THz}(750 \mathrm{~nm})$.

The concentration of nine elements $(\mathrm{Ca}, \mathrm{Cu}, \mathrm{Fe}, \mathrm{K}, \mathrm{Mg}, \mathrm{Na}, \mathrm{P}, \mathrm{S}$, and $\mathrm{Zn}$ ) in selected plasma samples were measured on an Optima 3000 inductive coupled plasma (ICP) emission spectroscopy analyser (Perkin Elmer, Norwalk, CT, USA). It appeared that the values of $c \mathrm{Zn}$ were $32 \pm 5 \mu \mathrm{mol} \mathrm{L}{ }^{-1}$, which is $2-4$ times the normal value. It is well known that in particular caps of test tubes like those used in this study may add zinc to plasma samples (Yngvar Thomassen, personal communication). Data on $c \mathrm{Zn}$ are therefore not given further consideration.

\section{Calculations}

Blood acid-base parameters were calculated along the principles of Siggaard-Andersen [39] as modified for use on modern computers [24]. The bicarbonate concentration is given as the "total" or titratable bicarbonate concentration that includes carbonate and carbamino compounds, both for plasma and for whole blood.

The (net) acid load on the blood was taken as the algebraic sum of the measured changes in the blood bicarbonate $\left(\Delta c \mathrm{HCO}_{3}^{-}{ }_{\mathrm{B}}\right)$ and blood base deficit $\left(\Delta c \mathrm{BD}_{\mathrm{B}}\right)$ concentrations from the normal values of 
$19.5 \mathrm{mmol} \mathrm{L}^{-1}\left(\mathrm{CHCO}_{3}^{-}{ }_{\mathrm{B}}\right)$ and $0 \mathrm{mmol} \mathrm{L}{ }^{-1}\left(c \mathrm{BD}_{\mathrm{B}}\right.$, see Ref. [24] for further details):

$$
c \text { Acid load }=\Delta c \mathrm{HCO}_{3}^{-}{ }_{\mathrm{B}}+\Delta c \mathrm{BD}_{\mathrm{B}}
$$

After exercise the bicarbonate concentration fell, and the net acid load is thus less than base deficit and reflects the part of base deficit load buffered by other means than bicarbonate.

Plasma anion gap concentration was taken as

$$
c \mathrm{AG}_{\mathrm{P}}=c \mathrm{Na}_{\mathrm{P}}^{+}+c \mathrm{~K}_{\mathrm{P}}^{+}-c \mathrm{Cl}_{\mathrm{P}}^{-}-c \mathrm{La}_{\mathrm{P}}^{-}-c \mathrm{HCO}_{3}^{-}
$$

Here $\mathrm{La}^{-}$denotes lactate ions, and the index ${ }_{\mathrm{P}}$ means that all entities refer to concentrations in plasma.

Red blood cell chloride concentration was calculated as

$$
c \mathrm{Cl}^{-}{ }_{\mathrm{C}}=\left(\left[0.658-0.350 \Delta \mathrm{pH}_{\mathrm{P}}\right] \cdot c \mathrm{Cl}_{\mathrm{P}}^{-}\right) \cdot \phi_{\mathrm{w}, \mathrm{C}} / \phi_{\mathrm{w}, \mathrm{P}}
$$

where $c \mathrm{Cl}^{-}$is the chloride concentration, the indices ${ }_{\mathrm{C}}$ and $\mathrm{P}$ refer to red blood cells and plasma, respectively, and $\phi_{\mathrm{w}, \mathrm{C}}$ and $\phi_{\mathrm{w}, \mathrm{P}}$ refer to the water fraction in the red blood cells and plasma, respectively. A separate analysis showed that the relative error of each estimated value was $\approx 2 \mathrm{mmol} \mathrm{L}^{-1}$ cell or $3 \%$ (not shown). The expression inside the curly brackets was taken from Funder and Wieth [8]. They expressed their concentrations on a molal basis (per $\mathrm{kg}$ of red blood cell or plasma water), while we report our values per litre of red blood cell or plasma volume. Conversions between mol L ${ }^{-1}$ and $\mathrm{mol} \mathrm{kg}^{-1}$ water were done using water fractions of $\phi_{\mathrm{w}, \mathrm{C}}=0.73$ and $\phi_{\mathrm{w}, \mathrm{P}}=0.94$ for red blood cells and plasma, respectively, (p. 79 in Ref. [39], taken from Ref. [9] assuming a red cell density of $\left.1.1 \mathrm{~kg} \mathrm{~L}^{-1}\right)$. It could be argued that if water leaves or enters the vascular bed or the red blood cells, the calculated values will be biased. However, if $10 \%$ of the plasma water was removed, water would still comprise $93.4 \%$ of the total plasma volume. Moreover, if $10 \%$ of the red cell water left the cell, water would still account for $70.9 \%$ of the red blood cell volume, showing that possible water fluxes have limited effect on the calculated intracellular concentration. Funder and Wieth [8] established the relationship above from measurements on fully oxygenated blood covering a large span of $\mathrm{CO}_{2}$ pressures and $\mathrm{pH}$-values, and only minimal deviations from the relationship were found [8]. Thus, the 
equation was assumed to hold for our blood samples too. Possible deviations for venous blood with reduced $\mathrm{O}_{2}$-saturation, are addressed in the discussion. Böning and co-workers [3] used a similar approach calculating $c \mathrm{Cl}^{-}$C from a relationship proposed by Dell and Winters [6]. Their approach reported identical values of that proposed above when correcting for different water fractions $\left(\phi_{\mathrm{w}, \mathrm{C}} / \phi_{\mathrm{w}, \mathrm{P}}\right)$.

The chloride concentration in red blood cells has been expressed per litre of whole blood by weighting (prescript w) for haematocrit (Hct), that is, the concentrations were multiplied by haematocrit:

$$
{\mathrm{w} c \mathrm{Cl}^{-}}_{\mathrm{C}}=c \mathrm{Cl}_{\mathrm{C}}^{-} \cdot \mathrm{Hct}
$$

The effect of a reduced $\mathrm{CO}_{2}$-pressure on acid-base status of the blood was calculated as follows: When $p \mathrm{CO}_{2}$ is reduced, bicarbonate reacts with hydrogen ions, forming carbonic acid and $\mathrm{CO}_{2}$. The hydrogen ions absorbed are taken from nonbicarbonate buffer bases (here symbolised as $\mathrm{X}^{\prime}$ along with Ref. [39]. Thus, $\mathrm{d} c \mathrm{HCO}_{3, \mathrm{~B}} / \mathrm{dpH}_{\mathrm{P}}=$ $-\mathrm{d} c \mathrm{X}_{\mathrm{B}}^{\prime} / \mathrm{dpH}_{\mathrm{P}}=\beta \mathrm{X}_{\mathrm{B}, \mathrm{P}}^{\prime}$ (p. 45 in Ref. )[39]. The latter expression denotes here the buffer capacity of nonbicarbonate buffers in whole blood expressed for a unit change in plasma $\mathrm{pH}$. It was calculated as explained elsewhere [24], and it appeared that $\beta \mathrm{X}_{\mathrm{B}, \mathrm{P}}^{\prime} \approx 29 \mathrm{mmol}$ $\mathrm{L}^{-1} \mathrm{pH}^{-1}$ for the present data. Thus, an increase $\Delta c \mathrm{X}_{\mathrm{B}}^{\prime}$ in $c \mathrm{X}_{\mathrm{B}}^{\prime}$ (and a corresponding decrease in the blood bicarbonate concentration) results in an increase in plasma $\mathrm{pH}$ of $\Delta \mathrm{pH}_{\mathrm{P}}=\Delta c \mathrm{X}_{\mathrm{B}}^{\prime} / \beta \mathrm{X}_{\mathrm{B}, \mathrm{P}}^{\prime}$. The bicarbonate concentration of whole blood can be taken from the concentration in plasma and vice versa (see p. 46 in Ref. [39] or Ref. [24] for details), and consequently the bicarbonate concentration in plasma can be calculated from the new, lower bicarbonate concentration in whole blood. The new $\mathrm{CO}_{2}$-pressure can now be calculated from the new $\mathrm{pH}_{\mathrm{P}}$ and $\mathrm{CHCO}_{3}{ }^{-} \mathrm{P}$ by solving the Henderson-Hasselbalch equation for $p \mathrm{CO}_{2}$. This procedure was iterated in steps of $\Delta c \mathrm{X}_{\mathrm{B}}^{\prime}=1 \mathrm{mmol} \mathrm{L}^{-1}$ or $\Delta c \mathrm{HCO}_{3}^{-}=-1 \mathrm{mmol} \mathrm{L}^{-1}$ to a $p \mathrm{CO}_{2}$ of $53 \mathrm{hPa}$ was found; a separate examination showed that steps much larger than $1 \mathrm{mmol} \mathrm{L}^{-1}$ did not introduce nonlinear effects (not shown). The amount of acid neutralised by reducing $p \mathrm{CO}_{2}$ was taken as the difference between the initial and final bicarbonate concentrations of whole blood. The effect of increasing $p \mathrm{CO}_{2}$ was calculated correspondingly. The numerical approach used is an Euler method [18] and was carried out in a spread sheet. 
The Bohr-Haldane effect was taken as the reduction in $\mathrm{O}_{2}$ saturation $\left(s \mathrm{O}_{2}\right)$ times blood haemoglobin concentration, using the Haldane coefficient $k_{\mathrm{H}}=-0.31$ (p. 79 in Ref. [39]):

$$
\beta_{\mathrm{BH}}=-k_{\mathrm{H}} \cdot\left(1-s \mathrm{O}_{2}\right) \cdot c \mathrm{Hb}_{\mathrm{B}}
$$

\section{Statistics}

The data are given as mean \pm SEM unless otherwise stated. Tests of statistical significance were carried out using $t$-tests. Linear regression was calculated as the geometric mean, thus taking into account that both parameters were subject to error [5, 35].

\section{RESULTS}

The subjects cycled at $5.48 \pm 0.17 \mathrm{~W} \mathrm{~kg}^{-1}$ for $122 \pm 7 \mathrm{~s}$ (mean $\pm \mathrm{SEM}$ ) to exhaustion.

\section{Time course of blood lactate and acid-base parameters}

The arterial blood lactate concentration rose during the exercise and peaked at $14 \mathrm{mmol} \mathrm{L}^{-1}$ in the interval $1-6 \mathrm{~min}$ after the exercise before declining (Figure 1a). The lactate concentration in femoralvenous blood was higher than that in arterial blood during the exercise and for the first $20 \mathrm{~min}$ of the recovery period. The lactate concentration in plasma was $\approx 60 \%$ higher than that in whole blood.

The bicarbonate concentration of both arterial and femoral-venous whole blood fell during the exercise and was around half the preexercise value in the early recovery before returning to the preexercise level in the late recovery (Figure 1c). The bicarbonate concentration in plasma was $20-25 \%$ higher than that in whole blood throughout the study. Thus for both lactate and bicarbonate the concentration in plasma was considerably higher than that in whole blood. Blood base deficit concentration rose during the exercise and further in the early recovery before returning to the pre-exercise value within $1 \mathrm{~h}$ of recovery (Figure 1e). In arterial blood standard base deficit was always within $1.0 \mathrm{mmol} \mathrm{L}^{-1}$ of the reported (actual) base deficit, and the changes in standard base deficit were in average 95\% of those of (actual) base deficit (not shown further). 

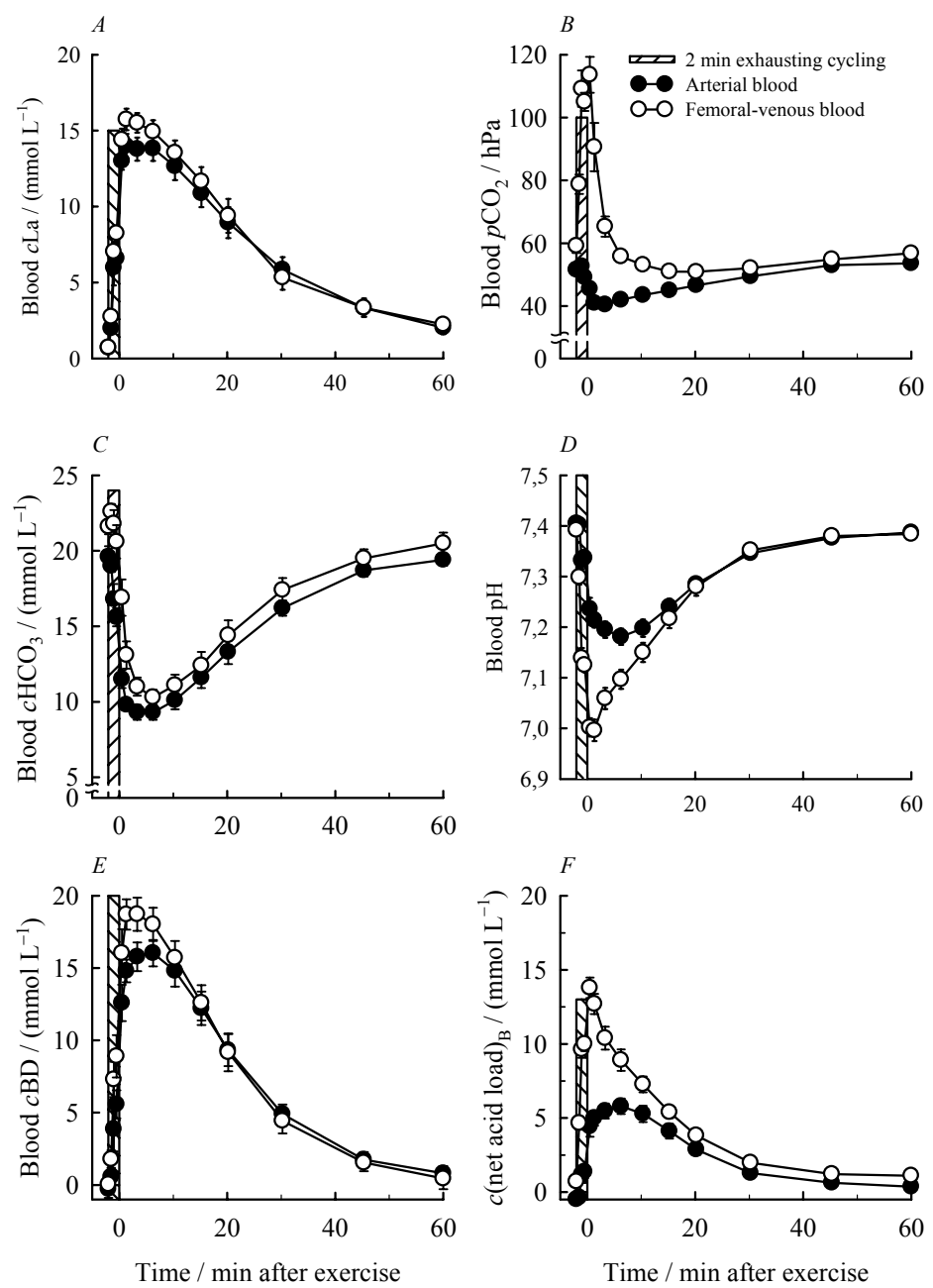

Figure 1. Blood lactate concentration and related acid-base parameters of arterial $(\bullet)$ and femoral-venous whole blood ( $($ ) during and after the exercise. $A$, blood lactate concentration $(c \mathrm{La}) ; B$, blood $\mathrm{CO}_{2}$ pressure $\left(p \mathrm{CO}_{2}\right) ; C$, whole blood bicarbonate concentration $\left(c \mathrm{HCO}_{3}^{-} \mathrm{B}\right) ; D, \mathrm{pH}$; $E$, blood base deficit $(c \mathrm{BD}) ; F$, net acid load on whole blood [ $c$ (net acid load $\left.)_{B}\right]$. The data are mean \pm SEM of seven subjects during 2 min cycling at constant power to exhaustion and for $1 \mathrm{~h}$ after the exercise. Error bars not shown are hidden by the symbols. 
The $\mathrm{CO}_{2}$-pressure $\left(p \mathrm{CO}_{2}\right)$ of arterial blood fell during the exercise and further in the early recovery, while $p \mathrm{CO}_{2}$ of femoral-venous blood doubled during exercise and dropped to below the pre-exercise level in the early recovery (Figure $1 \mathrm{~b}$ ). $p \mathrm{CO}_{2}$ was back to the pre-exercise level within 45 min after the exercise.

$\mathrm{pH}$ of arterial blood fell during the exercise and further in the early recovery (Figure 1d). $\mathrm{pH}$ of femoral-venous blood fell twice as much, reaching a lowest value of $7.00 \pm 0.02$ seen during the first minute of the recovery period. The arterial $\mathrm{pH}$ of $7.387 \pm 0.004$ seen $1 \mathrm{~h}$ after exercise was still below the pre-exercise value $(P=0.01)$.

The net acid load of the arterial blood rose during the exercise and further to a peak 6 min into the recovery period. The net acid load of femoral-venous blood rose more than twice as much (Figure 1f). One hour after exercise the net acid load of both arterial and femoralvenous blood was still above the pre-exercise level.

Table 1. Summary of the main blood values.

\begin{tabular}{|c|c|c|c|c|c|}
\hline \multirow{2}{*}{$\begin{array}{l}\text { Para- } \\
\text { meter }\end{array}$} & \multirow{2}{*}{$\begin{array}{c}\text { Unit of } \\
\begin{array}{c}\text { measure- } \\
\text { ment }\end{array}\end{array}$} & \multicolumn{2}{|c|}{ Before 2 min cycling } & \multicolumn{2}{|c|}{ Just after 2 min cycling } \\
\hline & & Artery & Vein & Artery & Vein \\
\hline$c \mathrm{La}_{\mathrm{B}}$ & $\mathrm{mmol} \mathrm{L}^{-1}$ & $0.7 \pm 0.2$ & $0.7 \pm 0.2$ & $13.0 \pm 0.7$ & $14.2 \pm 0.8$ \\
\hline $\mathrm{pH}$ & & $7.40 \pm 0.01$ & $7.39 \pm 0.01$ & $7.24 \pm 0.02$ & $7.00 \pm 0.02$ \\
\hline$p \mathrm{CO}_{2}$ & $\mathrm{hPa}$ & $51.6 \pm 1.8$ & $59.2 \pm 2.3$ & $45.5 \pm 0.9$ & $113.6 \pm 5.7$ \\
\hline$c \mathrm{HCO}_{3, \mathrm{~B}}$ & $\mathrm{mmol} \mathrm{L}^{-1}$ & $19.6 \pm 0.7$ & $21.6 \pm 0.5$ & $11.5 \pm 0.6$ & $16.9 \pm 1.2$ \\
\hline$c \mathrm{BD}_{\mathrm{B}}$ & $\mathrm{mmol} \mathrm{L}^{-1}$ & $-0.3 \pm 0.6$ & $0.0 \pm 0.6$ & $12.4 \pm 1.3$ & $16.4 \pm 1.7$ \\
\hline $\begin{array}{l}c \text { Acid } \\
\text { load }\end{array}$ & $\mathrm{mmol} \mathrm{L}^{-1}$ & $-0.5 \pm 0.2$ & $0.7 \pm 0.4$ & $4.4 \pm 0.7$ & $13.8 \pm 0.7$ \\
\hline$c \mathrm{Hb}_{\mathrm{B}}$ & $\mathrm{mmol} \mathrm{L}^{-1}$ & $9.64 \pm 0.20$ & $9.58 \pm 0.15$ & $10.39 \pm 0.21$ & $10.50 \pm 0.19$ \\
\hline Het & & $0.452 \pm 0.006$ & $0.458 \pm 0.008$ & $0.473 \pm 0.008$ & $0.491 \pm 0.006$ \\
\hline$p \mathrm{O}_{2}$ & $\mathrm{hPa}$ & $137 \pm 5$ & $57 \pm 5$ & $149 \pm 3$ & $43 \pm 10^{*}$ \\
\hline$s \mathrm{O}_{2}$ & & $0.963 \pm 0.006$ & $0.670 \pm 0.056$ & $0.965 \pm 0.007$ & $0.291 \pm 0.102$ \\
\hline$c \mathrm{O}_{2, \mathrm{~B}}$ & $\mathrm{mmol} \mathrm{L}^{-1}$ & $9.3 \pm 0.2$ & $6.4 \pm 0.6$ & $10.0 \pm 0.2$ & $3.1 \pm 1.1^{*}$ \\
\hline$c \mathrm{Alb}_{\mathrm{P}}$ & $\mathrm{mmol} \mathrm{L}^{-1}$ & $0.640 \pm 0.013$ & $0.652 \pm 0.024$ & $0.714 \pm 0.020$ & $0.791 \pm 0.032$ \\
\hline $\mathrm{w} c \mathrm{Alb}_{\mathrm{P}}$ & $\mathrm{mmol} \mathrm{L}^{-1}$ & $0.351 \pm 0.008$ & $0.353 \pm 0.012$ & $0.377 \pm 0.012$ & $0.396 \pm 0.012$ \\
\hline$\rho \operatorname{Pr}_{\mathrm{P}}$ & $\mathrm{g} \mathrm{L}^{-1}$ & $67.5 \pm 1.6$ & $67.0 \pm 1.8$ & $73.1 \pm 2.2$ & $77.3 \pm 1.9$ \\
\hline
\end{tabular}


The data are blood lactate concentration $\left(c \mathrm{La}_{\mathrm{B}}\right), \mathrm{pH}, \mathrm{CO}_{2}$-pressure $\left(p \mathrm{CO}_{2}\right)$, blood bicarbonate $\left(c \mathrm{HCO}_{3, \mathrm{~B}}\right)$, base deficit $\left(c \mathrm{BD}_{\mathrm{B}}\right)$, and haemoglobin concentrations $\left(c \mathrm{Hb}_{\mathrm{B}}\right)$, blood haematocrit (Hct), $\mathrm{O}_{2}$-pressure $\left(\mathrm{O}_{2}\right), \mathrm{O}_{2}$-saturation $\left(s \mathrm{O}_{2}\right)$ and blood $\mathrm{O}_{2}$-concentration $\left(c \mathrm{O}_{2, \mathrm{~B}}\right)$. All data refer to the values in whole blood. Further follows plasma albumin concentration $\left(c \mathrm{Alb}_{\mathrm{P}}\right)$, plasma albumin concentration weighted for haematocrit $\left(\mathrm{w} c \mathrm{Alb} \mathrm{P}_{\mathrm{P}}\right)$ and plasma protein mass concentration $\left(\rho \operatorname{Pr}_{\mathrm{P}}\right)$. ${ }^{*}$ The blood samples just after 2 min cycling were drawn 20-30 s after the end of exercise. $p \mathrm{O}_{2}, s \mathrm{O}_{2}$ and $c \mathrm{O}_{2}$ of femoralvenous blood near the end of exercise were $\approx 30 \mathrm{hPa}\left(p \mathrm{O}_{2}\right),<0.2\left(s \mathrm{O}_{2}\right)$ and $<2 \mathrm{mmol} \mathrm{L}^{-1}\left(c \mathrm{O}_{2, \mathrm{~B}}\right)$. The data are mean \pm SEM of seven subjects.

Blood haemoglobin concentration rose by $8 \%$ during the exercise, thus reflecting haemoconcentration (Table 1). The concentration fell in the recovery period, was back to the pre-exercise level within $15 \mathrm{~min}$ and below that level from $30 \mathrm{~min}$ after the exercise. Haematocrit of arterial blood rose during the exercise and peaked $7 \%$ above the pre-exercise value $3 \mathrm{~min}$ into the recovery. Haematocrit of femoralvenous blood was $9 \%$ above the pre-exercise level at exhaustion. Haematocrit fell to the pre-exercise level within $20 \mathrm{~min}$ and was below that level from 30 min into the recovery period.

The ratio between plasma albumin concentration weighed for haematocrit and blood haemoglobin concentration was $0.0367 \pm 0.0014$ $(\mathrm{mol} \mathrm{Alb} / \mathrm{mol} \mathrm{Hb})$ before the exercise. There was at no time point any statistically significant arterial-femoral-venous difference for this ratio, nor did this ratio change during the exercise or in the recovery period. These data thus suggest that the vascular contents of albumin and haemoglobin were constant or changed in parallel during the study.

\section{Scatterplots of acid-base parameters}

$p \mathrm{CO}_{2}$ and $\mathrm{pH}$ of the arterial blood fell by the blood lactate concentration (Figure 2A, C), and consequently the bicarbonate concentration of arterial blood fell by $0.8 \mathrm{mmol} \mathrm{L}^{-1}$ for a $1 \mathrm{mmol} \mathrm{L}^{-1}$ increase in the blood lactate concentration (Figure 2E). Arterial base deficit concentration rose $30 \%$ more than blood lactate concentration did (Figure 2G). These data thus show that in average bicarbonate and other, nonbicarbonate buffers each buffered $63 \%\left(\mathrm{HCO}_{3}{ }^{-}\right)$and $37 \%$ (nonbicarbonate buffers), respectively, of the total acid load on arterial blood. 
$p \mathrm{CO}_{2}$ of femoral-venous blood $\left(p \mathrm{CO}_{2, \mathrm{fv}}\right)$ doubled during the last minute of the exercise and stayed high for the first minute of the recovery period (Figure $1 \mathrm{~B}$ ). These values with a $p \mathrm{CO}_{2, \mathrm{fv}}>80 \mathrm{hPa}$ are therefore marked separately in Figure 2 and are not included in the regression analyses. $p \mathrm{CO}_{2, \mathrm{fv}}$ was systematically higher than that of arterial blood with the same lactate concentration, and $p \mathrm{CO}_{2, \mathrm{fv}}$ showed no simple relationship to the lactate concentration (Figure 2B). $\mathrm{pH}$ of femoral-venous blood fell by the lactate concentration (Fig. 2D). Even when disregarding samples with $\mathrm{pCO}_{2}>80 \mathrm{hPa}, \mathrm{pH}$ in femoral-venous blood was 0.03-0.06 less than that in arterial blood with the same lactate concentration, and the relationship was slightly curved. The bicarbonate concentration of femoral-venous blood fell by the blood lactate concentration. When excluding samples with $p \mathrm{CO}_{2}>80 \mathrm{hPa}$, there was a relationship almost parallel to that of arterial blood but displaced to $1.7 \mathrm{mmol} \mathrm{L}^{-1}$ higher bicarbonate concentrations for the same lactate concentration (Figure 2F). The base deficit concentration of femoral-venous blood rose showed almost the same relationship to lactate concentration as seen in arterial blood, and there was no difference between samples with high and low $p \mathrm{CO}_{2}$ (Figure $2 \mathrm{H}$ ). When excluding samples with $p \mathrm{CO}_{2, \mathrm{fv}}>80 \mathrm{hPa}$, bicarbonate buffered $61 \%$ of all acid added to the femoral-venous blood, a value very close to that of arterial blood.

The dashed lines in $E$ and $G$ are lines of identity, that is, relationships assuming that each lactate ion added to the blood replaced one bicarbonate ion $(E)$, and that each lactate ion added to the blood was accompanied by one and only one hydrogen ion $(G)$. The difference between the solid and the dashed line in $G$ thus shows the excess hydrogen ions added to the arterial blood. The dotted line in $G$ is taken from the regression line in $E$, that is, by assuming that the amount of hydrogen ions added to the blood equalled the amount of bicarbonate ions disappearing. The difference between the solid and dotted line thus shows the amount of hydrogen ions buffered by nonbicarbonate buffers. The data are from seven subjects who cycled at constant power for $2 \mathrm{~min}$ to exhaustion and were followed for $1 \mathrm{~h}$ after. 

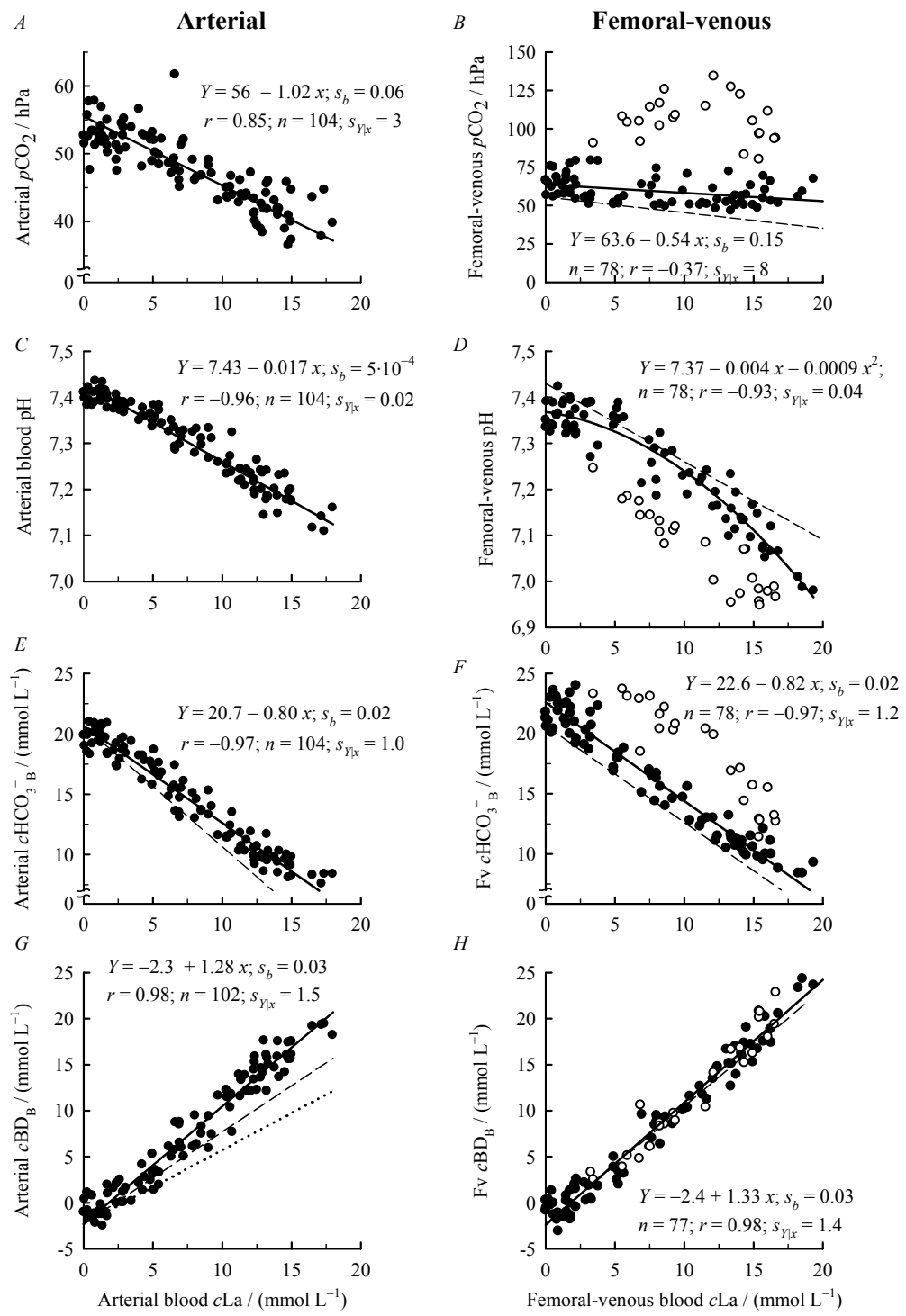

Figure 2. Arterial (left panels) and femoral-venous acid-base parameters (right panels) versus blood lactate concentration. Top row, blood $p \mathrm{CO}_{2}$; second row, blood $\mathrm{pH}$; third row, whole blood bicarbonate concentration; bottom row, blood base deficit. The solid lines are the regression lines 
with the relevant regression parameters given in each panel. For femoralvenous plots (right) the corresponding regression line of arterial data is shown as a dashed line, and the difference between each pair of lines thus shows the difference between arterial and femoral-venous blood for the same lactate concentration. For femoral-venous blood $\circ$ refers to samples taken during the last minute of the exercise and for the first minute after, that is samples with $p \mathrm{CO}_{2}>80 \mathrm{hPa}$; these values are not included in the calculated regressions. $\bullet$ refers to all other blood samples and on which values the regressions are based.

\section{Plasma electrolyte concentrations}

The plasma sodium concentration rose by $10 \mathrm{mmol} \mathrm{L}^{-1}$ during the 2 min exhausting exercise, mainly as a consequence of haemoconcentration during exercise, while the chloride concentration rose somewhat less (Table 2). The plasma potassium concentrations measured $\approx 30 \mathrm{~s}$ after the exercise was $2.3 \mathrm{mmol} \mathrm{L}^{-1}$ higher than before the ride. The plasma lactate concentration rose by $20 \mathrm{mmol} \mathrm{L}^{-1}$, while the plasma bicarbonate concentration fell by around half this value (Figure 3A). Therefore, the sum of these two ion concentrations rose during the exercise, and more so for femoral-venous than for arterial plasma. Consequently, anion gap fell during the exercise, and more so for femoral-venous than for arterial plasma (Figure 3B). Anion gap rose linearly by $\mathrm{pH}$, whether expressed in absolute terms (Figure $3 \mathrm{C}$ ) or as anion gap weighted for changes in haematocrit $\left[\mathrm{wcAG}_{\mathrm{P}} /(\mathrm{mmol}\right.$ $\left.\left.\mathrm{L}^{-1}\right)=6.8+13.3(\mathrm{pH}-7.4) ; s_{b}=0.8 ; s_{Y \mid x}=1.1 ; r=0.75\right]$. There was no difference between arterial and femoral-venous samples. One hour after the exercise all plasma electrolyte concentrations except those of lactate and bicarbonate were back to the pre-exercise values, and the anion gap was restored. 
Table 2. Summary of plasma electrolytes and derived quantities.

\begin{tabular}{|l|c|c|c|c|c|}
\hline $\begin{array}{l}\text { Para- } \\
\text { meter }\end{array}$ & Unit of & \multicolumn{2}{|c|}{ Before 2 min cycling } & \multicolumn{2}{c|}{ Just after 2 min cycling } \\
\hline $\begin{array}{c}\text { measure- } \\
\text { ment }\end{array}$ & Artery & Vein & Artery & Vein \\
\hline$c \mathrm{Na}_{\mathrm{P}}^{+}$ & $\mathrm{mmol} \mathrm{L}^{-1}$ & $134.5 \pm 1.2$ & $135.3 \pm 1.1$ & $143.9 \pm 1.9$ & $147.0 \pm 1.9$ \\
\hline$c \mathrm{~K}_{\mathrm{P}}^{+}$ & $\mathrm{mmol} \mathrm{L}^{-1}$ & $3.84 \pm 0.06$ & $3.83 \pm 0.09$ & $6.11 \pm 0.27^{*}$ & $6.21 \pm 0.39^{*}$ \\
\hline$c \mathrm{Cl}_{\mathrm{P}}^{-}$ & $\mathrm{mmol} \mathrm{L}^{-1}$ & $101.8 \pm 0.6$ & $100.5 \pm 0.4$ & $107.9 \pm 1.3$ & $105.3 \pm 1.3$ \\
\hline$c \mathrm{La}_{\mathrm{P}}^{-}$ & $\mathrm{mmol} \mathrm{L}^{-1}$ & $1.4 \pm 0.3$ & $1.6 \pm 0.3$ & $20.0 \pm 1.4$ & $23.1 \pm 1.6$ \\
\hline$c \mathrm{HCO}_{3, \mathrm{P}}^{-}$ & $\mathrm{mmol} \mathrm{L}^{-1}$ & $24.0 \pm 0.6$ & $26.6 \pm 0.8$ & $14.1 \pm 0.8$ & $20.2 \pm 1.4$ \\
\hline$c \mathrm{AG}_{\mathrm{P}}$ & $\mathrm{mmol} \mathrm{L}^{-1}$ & $11.1 \pm 0.7$ & $10.3 \pm 0.7$ & $8.1 \pm 1.1$ & $4.7 \pm 0.8$ \\
\hline$c \mathrm{Cl}_{\mathrm{C}}^{-}$ & $\mathrm{mmol} \mathrm{L}^{-1}$ & $57.8 \pm 0.3$ & $59.0 \pm 0.2$ & $66.1 \pm 0.9$ & $70.4 \pm 0.8$ \\
\hline $\mathrm{WcCl}_{\mathrm{C}}^{-}$ & $\mathrm{mmol} \mathrm{L}^{-1}$ & $23.5 \pm 0.4$ & $24.3 \pm 0.4$ & $28.5 \pm 0.4$ & $32.7 \pm 0.9$ \\
\hline
\end{tabular}

The data are plasma electrolytes $\left(\mathrm{Na}^{+}, \mathrm{K}^{+}, \mathrm{Cl}^{-}\right.$, lactate and bicarbonate), and anion gap $\left(c \mathrm{AG}_{\mathrm{P}}\right)$. Finally, calculated concentration of chloride in red blood cells $\left(\mathrm{CCl}_{\mathrm{C}}^{-}\right)$and weighted for haematocrit $\left(\mathrm{wcCl}_{\mathrm{C}}^{-}\right) .{ }^{*}$ The blood samples just after 2 min cycling were drawn 20$30 \mathrm{~s}$ after the end of the exercise. $c \mathrm{~K}_{\mathrm{p}}^{+}$near the end of exercise was $\approx 7 \mathrm{mmol} \mathrm{L}$. The data are mean \pm SEM of seven subjects.

The ratio between the plasma sodium concentration weighted for haematocrit and blood haemoglobin concentration $\left[c \mathrm{Na}^{+}{ }_{\mathrm{P}}(1-\mathrm{Hct}) /\right.$ $\left.c \mathrm{Hb}_{\mathrm{B}}\right]$, was $7.7 \pm 0.2\left(\mathrm{mmol} \mathrm{Na}{ }^{+} / \mathrm{mmol} \mathrm{Hb}\right)$ for both arterial and femoral-venous blood before the exercise. The ratio fell to $7.3 \pm 0.2$ $(\mathrm{aP},-5 \%)$ and $7.0 \pm 0.2(\mathrm{fvP},-9 \%)$ at exhaustion and stayed at those levels for the following $6 \mathrm{~min}$. During this period there was a significant a-fv difference, compatible with an uptake of sodium in the leg (see Ref. [24] for further details and interpretation). Since we in the recovery period flushed the catheters with a heparinised isotonic $\mathrm{NaCl}$-solution, changes later in the recovery are difficult to interpret physiologically, and further data are therefore not given. 


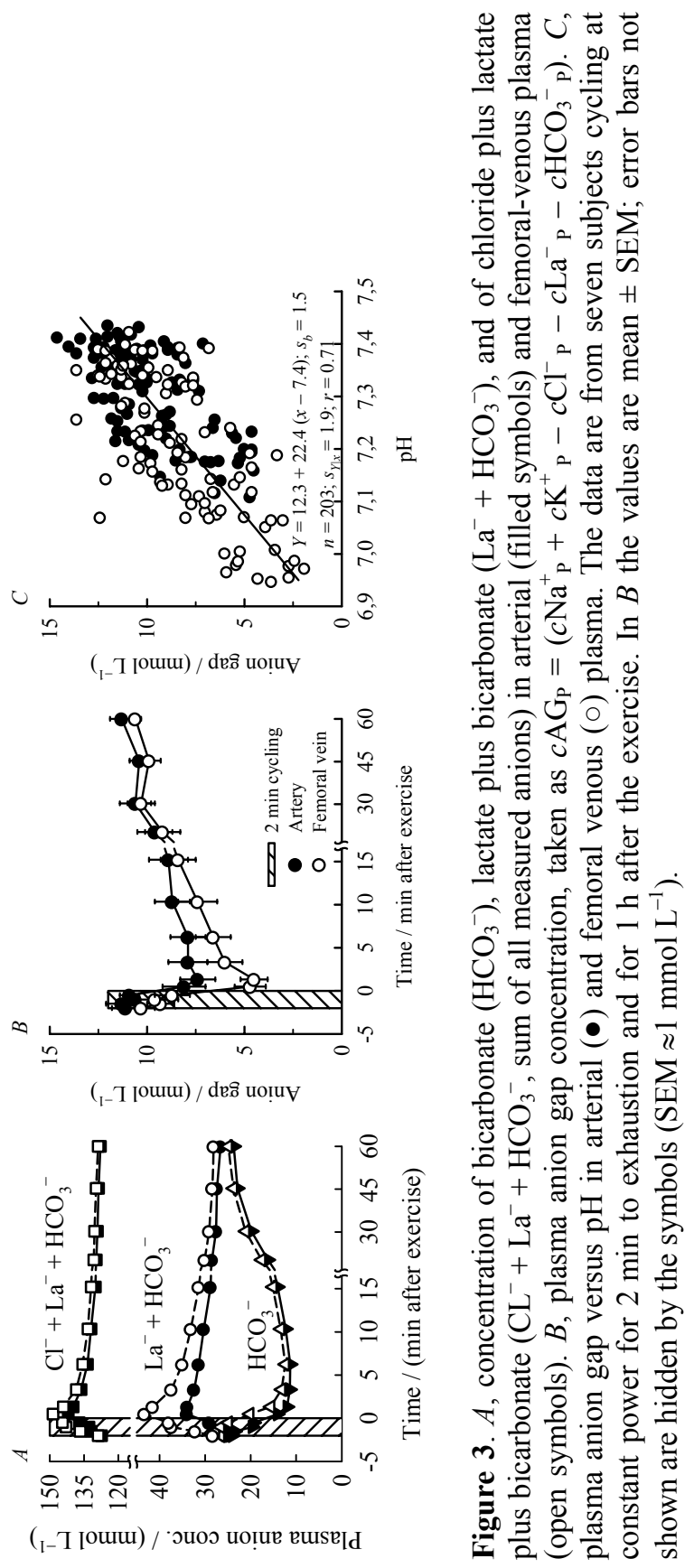


In arterial blood the relationship between plasma bicarbonate and lactate concentrations was $c \mathrm{HCO}_{3, \mathrm{aP}}=25 \mathrm{mmol} \mathrm{L}-1$ $\left(s_{b}=0.02, s_{Y \mid x}=1.7 \mathrm{mmol} \mathrm{L}^{-1}, n=105, r=-0.95\right)$. The corresponding relationship for plasma from femoral-venous blood was $c \mathrm{HCO}_{3, \mathrm{fvP}}=$ $27 \mathrm{mmol} \mathrm{L}^{-1}-0.63 c \mathrm{La}_{\mathrm{aP}}\left(s_{b}=0.02, s_{Y \mid x}=1.8 \mathrm{mmol} \mathrm{L}^{-1}, n=74\right.$, $r=-0.95)$ when samples with a $p \mathrm{CO}_{2}>80 \mathrm{hPa}$ were excluded. The slopes of the two relationships do not differ. Thus, in average a $1 \mathrm{mmol} \mathrm{L}{ }^{-1}$ increase in the plasma lactate concentration resulted in a $0.64 \mathrm{mmol} \mathrm{L}^{-1}$ drop in the plasma bicarbonate concentration.

Concentrations of eight elements in plasma. The concentrations of eight elements in plasma $(\mathrm{Ca}, \mathrm{Cu}, \mathrm{Fe}, \mathrm{K}, \mathrm{Mg}, \mathrm{Na}, \mathrm{P}$, and $\mathrm{Sn}$ ) were measured before the exercise and $1 \mathrm{~min}$ after the exercise. There was no major change during the exercise nor any major a-fv differences, and the moderate changes and differences seen are compatible with haemoconcentration and the fluid shift that took place.

\section{Red blood cell chloride concentration}

The calculated chloride concentration rose by $8(+15 \%)$ and $12 \mathrm{mmol} \mathrm{L}^{-1}(+23 \%)$ for arterial and femoral-venous red blood cells, respectively, during the exercise. To correct for fluid shifts between plasma and red blood cells, the concentration were expressed per litre of whole blood by weighing the concentrations expressed per litre of cell volume for haematocrit. The weighted chloride concentration rose by $21 \%$ (a) and by $34 \%$ (fv) during the exercise (Figure $4 \mathrm{~A}$, Table 2 ). The chloride concentrations of red blood cells fell in the recovery. From $10 \mathrm{~min}$ into the recovery period the weighed chloride concentration of femoral-venous red blood cells did not differ from that of arterial blood.

The weighted chloride concentration of red blood cells rose linearly by the net acid load on blood and by reduced $\mathrm{pH}$ (Figure $4 \mathrm{~B}, \mathrm{C})$. The weighed chloride concentrations of the red blood cells was in average $0.6 \mathrm{mmol} \mathrm{L}^{-1}$ less in femoral-venous than in arterial blood for the same blood $\mathrm{pH}$ or acid load. The calculated chloride uptake of the red blood cells amounted to $82 \%$ of the net acid load on the blood (Figure 4B). 


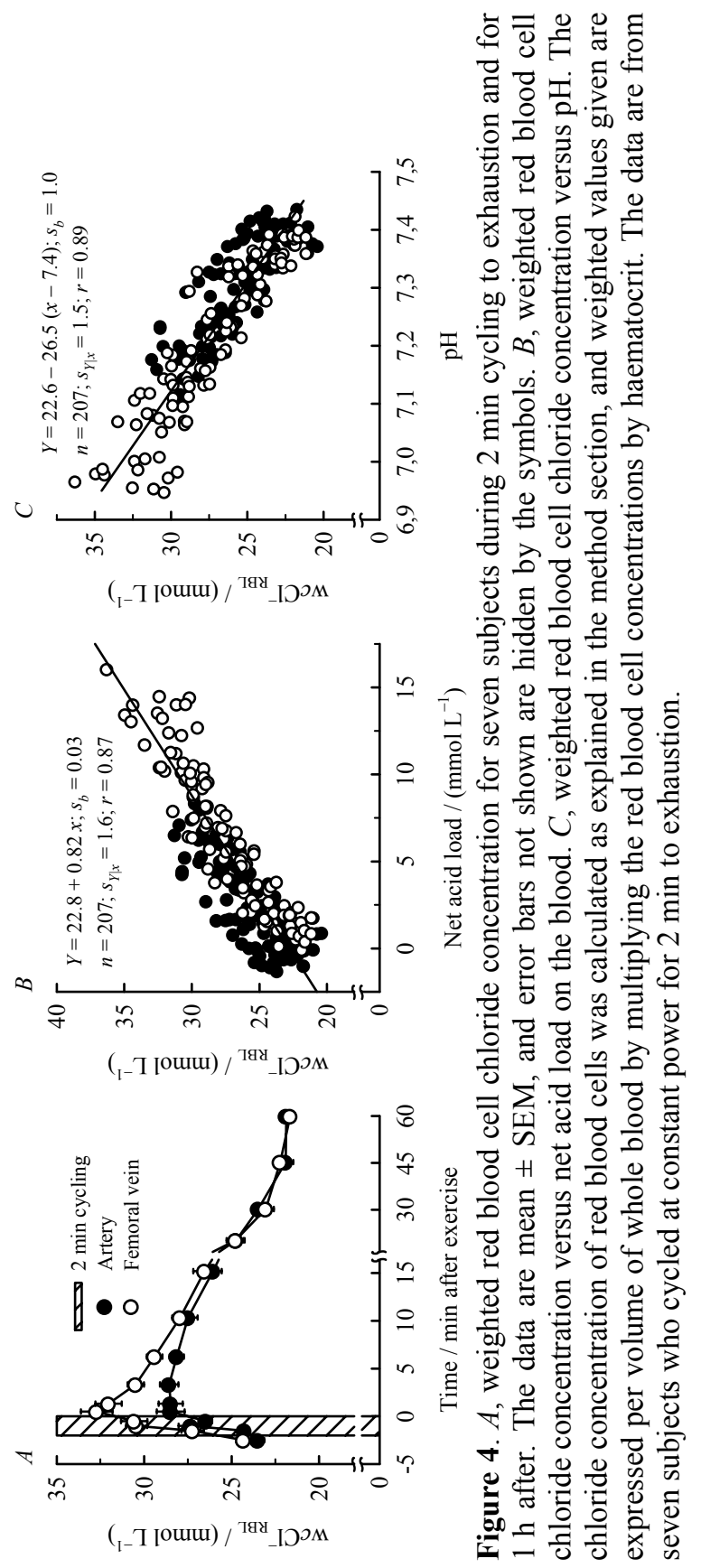




\section{DISCUSSION}

Blood $\mathrm{pH}$ fell by increasing blood lactate concentrations, and more so in femoral-venous blood with either an additional respiratory acidosis or only limited respiratory compensation. Blood base deficit concentration rose $30 \%$ more than the blood lactate concentration did, and the relationship did not differ between arterial and femoral-venous blood with different $p \mathrm{CO}_{2}$. Bicarbonate buffered in average $62 \%$ of the hydrogen ions added to the blood. Chloride left the plasma space and entered red blood cells in proportion to the net acid load or change in $\mathrm{pH}$ and amounted to $>30 \%$ of the total acid load. Plasma anion gap fell linearly by a falling $\mathrm{pH}$ or increasing acid load.

\section{Comparison with former studies}

Blood lactate concentration rose during the exercise and continued to rise for a few minutes into the recovery period and fell thereafter. This pattern and the values seen are in line with several former studies [3, $4,24,27,33,36,43]$. Blood and plasma bicarbonate concentration fell linearly by the lactate concentration, which is in line with data from former studies $[4,27,33]$. In arterial blood $p \mathrm{CO}_{2}$ fell linearly by the blood lactate concentration or the degree of acidosis, as has also been shown earlier [27]. Thus, our data on arterial blood are in line with former studies. During exercise there was no respiratory compensation in femoral-venous blood but in fact a doubling of the $p \mathrm{CO}_{2}$ near the end of the exercise and in the early recovery, thus adding a respiratory acidosis to the metabolic one. That observation is in line with that of Sahlin and coworkers [37]. Finally, the observed changes in plasma chloride concentration are in line with a recent study [3]. Thus, when comparisons are possible, our data are in line with former studies and thus appear typical for very intense exercise. Consequently, it is therefore conceivable that further analyses and calculations on our data are not atypical.

\section{Acid-base status of arterial and femoral-venous blood}

For arterial blood $\mathrm{pH}, p \mathrm{CO}_{2}$, and the bicarbonate concentration all fell linearly by increasing lactate concentrations, while base deficit rose linearly by the lactate concentration. For femoral-venous blood there were corresponding relationships between $\mathrm{pH}$ and bicarbonate concentration versus blood lactate concentration when samples with particularly high $p \mathrm{CO}_{2}$ were excluded. The relationship between blood 
base deficit and blood lactate concentrations did not differ systematically between arterial and femoral-venous blood, nor did base deficit differ between samples with high and low $p \mathrm{CO}_{2}$. The latter observation suggests that respiratory acidosis or alkalosis had no influence on the calculated base deficit concentration, which was to be expected since base deficit measures the metabolic or nonrespiratory component of the acidosis in blood. The finding that base deficit did not differ between arterial and femoral-venous blood with the same lactate concentration even when $\mathrm{pH}$ differed, suggests that the differences in $\mathrm{pH}$ and acid-base status between arterial and femoralvenous blood was due to different degrees of respiratory acidosis or compensation.

Just after exercise $\mathrm{pH}$ differed by as much as 0.2 between arterial and femoral-venous blood, and the main reason was different $p \mathrm{CO}_{2}$, as has been shown earlier [36]. These results thus show the importance of $p \mathrm{CO}_{2}$ for blood $\mathrm{pH}$, as has been addressed in a recent review [16].

\section{Base deficit and excess hydrogen ions}

Blood base deficit changed $\approx 30 \%$ more than the blood lactate concentration did. This is compatible with the idea that also hydrogen ions of nonlactic and noncarbonic origin appeared in the blood. It was first suggested that lactate and hydrogen ions appeared in equal amounts in the blood [43]. Later studies found that base deficit exceeded the blood lactate concentration after intense exercise. One interpretation was that the excess seen meant that base deficit overestimated the amounts of hydrogen ions added to blood [4, 33]. It was later shown that there was an excess of hydrogen ions added to blood in the early recovery period after intense exercise [2, 27, 36], at the same time as muscle $\mathrm{pH}$ recovers much faster than muscle lactate concentration does $[13,14,38]$, compatible with the idea that muscle removed hydrogen ions to the blood independently of lactate ions in the early recovery after intense exercise. It is now known that muscle can release hydrogen ions independently of lactate $[2,17,21]$. We have more recently shown that in the leg sodium ions left plasma in equal amounts to the excess hydrogen ions appearing in the blood after intense exercise [24]. Those data are compatible with an activation of a $\mathrm{Na}^{+}, \mathrm{H}^{+}$-exchange in the early recovery, which is well established to take place for the amiloride-sensitive $\mathrm{Na}^{+}, \mathrm{H}^{+}$-exchanger when muscle $\mathrm{pH}$ is reduced [21]. Thus, we now know that base deficit is an accurate measure of the metabolic acidosis in blood and that the 
excess hydrogen ions appearing in the blood after exercise is a physiologic phenomenon reflecting processes with well established mechanisms.

The view of excess hydrogen ions released to blood has recently been questioned by Böning and co-workers who found that changes in standard base deficit, assumed to measure metabolic acidosis averaged over the whole extracellular compartment, equalled the calculated extracellular lactate concentration [3]. Their approach assumes sufficiently fast equilibration of lactic acid and bicarbonate in all extracellular space, which may not be the case [30]. A further discussion of possible excess release of hydrogen ions is beyond the scope of the present paper.

\section{Uptake of chloride in red blood cells}

Chloride left plasma and entered the red blood cells in proportion to the change in $\mathrm{pH}$ and to the net acid load. Chloride shift and its relation to $p \mathrm{CO}_{2}$ and blood acid-base status has been known for more than hundred years $[12,32]$. The phenomenon was later shown to be due to a property of red blood cells and not of plasma [7], to be a chloride-bicarbonate-exchange across the red cell membrane [15], and to be a very fast process, reaching equilibrium within $1 \mathrm{~s}[19,42]$. Bicarbonate neutralised most of the hydrogen ions added to the blood, but of the remaining hydrogen ions added, our data suggest that $82 \%$ could be accounted for by processes related to chloride uptake in red blood cells. Thus, the calculated chloride shift amounted in average to $31 \%$ of the total acid load on the blood.

At each time point the chloride concentration in red blood cells was higher in femoral-venous than in arterial blood. That observation is compatible with an uptake of chloride by the red blood cells in exchanged with bicarbonate in the peripheral capillaries (and a reversal in the lungs). Our data show in addition that the chloride concentration in red blood cells rose by a falling $\mathrm{pH}$ or an increasing net acid load. Since plasma bicarbonate concentration fell during these conditions, this means that the cells took up chloride during acidosis while the bicarbonate concentration in plasma fell. It is likely that excess hydrogen ions in plasma have reacted with bicarbonate, thus forming $\mathrm{CO}_{2}$ that have diffused into the red blood cells, formed bicarbonate that again have been exchanged with chloride in plasma, a process known as the Jacobs-Steward cycle [15]. The process may 
take place even without carbonic anhydrase available in plasma, but then requiring $1 \mathrm{~min}$ or more for approaching equilibrium.

The chloride concentration in red blood cells was in this study not measured but calculated from the measured $\mathrm{pH}$ and plasma chloride concentration using equation [3] taken from [8]. Funder and Wieth established their relationship from measurements covering a large span of $p \mathrm{CO}_{2}$ - and $\mathrm{pH}$-values, but only on fully oxygenated blood. They found no systematic deviations from the relationship they established, and a separate analysis on their data showed that the error in each estimate was $\approx 2 \mathrm{mmol} \mathrm{L}^{-1}$ or $3 \%$. Dell and Winters [6] developed the same relationships using others data. Thus, two independent sets of data support our calculated chloride concentrations. Others have calculated the chloride concentration of red blood cells from the measured amounts of chloride in haemolysed whole blood and plasma $[22,23]$. That approach that is less precise than direct measurements but would expectedly not introduce systematic errors. The chloride concentration of red blood cells in two other studies rose almost as much as in our study [3,23]. Thus, these studies give further support to our data on the red blood cell chloride concentration calculated from equation [3]. However, as discussed below, our calculations may have underestimated the uptake in red blood cells of deoxygenated femoral-venous blood. Thus, in future studies red blood cell chloride concentration should be measured directly, at least in deoxygenated venous blood.

\section{Plasma electrolyte balance}

The pooled concentration of cations and anions in plasma rose during the exercise, and the plasma volume fell, as shown by the increased albumin concentration. Haemoconcentration is one major reason for the increases in plasma electrolyte concentrations. However, several factors modified this picture. Most important is that during the exercise and for the first minutes after lactate replaced bicarbonate in plasma at a ratio of $\approx 1: 0.64$ (mot including femoral-venous samples with $p \mathrm{CO}_{2}>80 \mathrm{hPa}$ ). In addition, both sodium and chloride left the plasma space. While sodium was probably taken up by acidotic muscle cells in exchange with $\mathrm{H}^{+}$[24] chloride was most likely taken up by the red blood cells. Finally, the plasma potassium concentration rose during the exercise and fell in the early recovery period, as studied in much more detail elsewhere [28]. 
The concentration of anions raised more than the concentration of cations did, mainly because of the smaller loss of bicarbonate than accumulation of lactate. Consequently, plasma anion gap concentration fell linearly by a falling $\mathrm{pH}$ or by an increasing net acid load, that is, by an increasing lactate concentration. That finding is in apparent conflict with our former study where we reported an apparent increase in the calculated anion gap after the exercise [27]. However, in that study we compared the lactate concentration in whole blood with the concentration of bicarbonate and other electrolytes in plasma. In the present study the plasma lactate concentration was as much as $10 \mathrm{mmol} \mathrm{L}^{-1}$ higher than the concentration in whole blood, and this difference may explain the whole difference between the two studies.

Anion gap reflects the net negative electric charge on electrolytes that have not been measured, preferentially on plasma proteins. It could be that plasma exchanged other ions. That possibility was examined by measuring the concentrations of eight elements in plasma samples taken before the exercise and $1 \mathrm{~min}$ into the recovery. These analyses showed only moderate changes in the concentration of each of the measured elements, compatible with haemoconcentration and fluid shift and thus suggest that there was no detectable exchange between muscle, plasma, and red blood cells of the measured elements or ions other than sodium, potassium, chloride, lactate, and bicarbonate. Moreover, the production and release of pyruvate from muscle is minimal $[4,36]$. However, anion gap fell by $22.4 \mathrm{mmol} \mathrm{L}^{-1}$ for a unit drop in plasma $\mathrm{pH}$. If that value did reflect buffering by plasma proteins, the slope would correspond to a buffer capacity of $>0.3 \mathrm{mmol} \mathrm{pH}^{-1} \mathrm{~g}^{-1}$ protein, which is three times the value found by others by titration of plasma (p. 42 in Ref. [39]). A correction for changes in the protein mass concentrations during the study has no influence on this conclusion (not shown). Thus, it could also be that the concentration of other ions in plasma, perhaps some organic ions, was changed after the exercise. The results of a change in anion gap in excess of changed charge of plasma proteins is in line with data of Adrogue and co-workers [1] who also proposed changes in unmeasured organic anions as a likely explanation.

The ratio between blood concentrations of albumin and haemoglobin was constant throughout the study, meaning that the vascular content of both species was probably constant, apart from loss due to blood sampling. The mass concentration of plasma proteins rose relatively less than the albumin concentration. That observation is 
compatible with loss of plasma proteins other than albumin during exercise and in the early recovery, as also suggested by another study [22].

\section{Neutralisation of acids added to the blood}

In femoral-venous blood base deficit rose by $20 \mathrm{mmol} \mathrm{L}^{-1}$ at the extreme. Blood $\mathrm{pH}$ fell from 7.4 to 7.0 , which is an increase in the activity of hydrogen ions from 40 to $100 \mathrm{nmol} \mathrm{L}^{-1}$. Using an activity coefficient of 0.84 (p. 28 in Ref. [39], this corresponds to an increase in the concentration of free hydrogen ions of $\approx 70 \mathrm{nmol} \mathrm{L} \mathrm{L}^{-1}$. This means that for each million of hydrogen ions added to the blood, less than four remained free at any time while the others were neutralised. A corresponding calculation for the data on arterial blood shows that less than three out of one million hydrogen ions released to the blood were free. Blood has several means of neutralising added acids. Bicarbonate may react with hydrogen ions, form carbonic acid that again is split to water and $\mathrm{CO}_{2}$ that may be lost through the lungs. It appeared that $\approx 62 \%$ of the total acid load, taken as the base deficit, was neutralised by bicarbonate in both arterial and femoral-venous blood (disregarding samples with $p \mathrm{CO}_{2}>80 \mathrm{hPa}$ ). Thus, bicarbonate was quantitatively the most important means of neutralising acids added to the blood.

Our data suggest that of the portion of hydrogen ions added to the blood but not neutralised by bicarbonate, $82 \%$ entered the red blood cells by a chloride shift and were buffered intracellularly. That amounts in average to $31 \%$ of the total acid load (base deficit). Thus, other means accounted for only $7 \%$ of the total acid load.

The magnitude of base deficit, its components and how this acid load was accounted for, is shown in Figure 5. In arterial samples reduction of blood bicarbonate concentration neutralised in both cases $61 \%$ of the acid load, taken as the base deficit concentration. The main component was due to the effect of a reduced bicarbonate concentration as $\mathrm{pH}$ fell, keeping the $\mathrm{CO}_{2}$-pressure constant. As a consequence of hypervention $p \mathrm{CO}_{2}$ of arterial blood fell to $41-45 \mathrm{hPa}$, which reduced the bicarbonate concentration further by $\approx 1 \mathrm{mmol} \mathrm{L}^{-1}$ and thus neutralised the same amount of hydrogen ions. In femoralvenous blood $p \mathrm{CO}_{2}$ was increased, and that led to an extra acid load of to $5.3 \mathrm{mmol} \mathrm{L}^{-1}(0 \mathrm{~min}, \mathrm{fv})$ and $0.4 \mathrm{mmol} \mathrm{L}^{-1}(6 \mathrm{~min}, \mathrm{fv})$. 


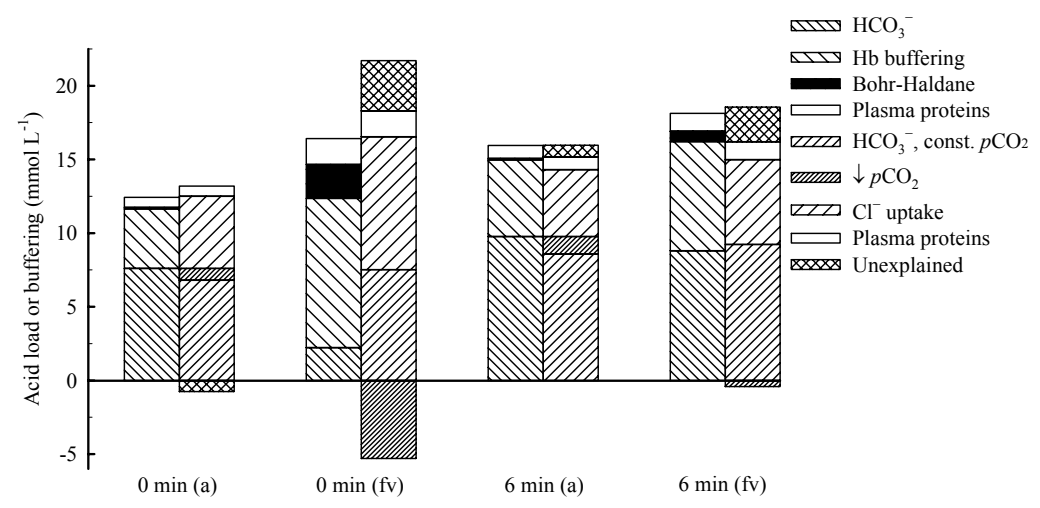

Figure 5. Left column in each pair, components of base deficit taken as (bottom to top) a reduced bicarbonate concentration in whole blood $\left(\mathrm{HCO}_{3}{ }^{-}\right)$, buffering on haemoglobin without the Bohr-Haldane effect $(\mathrm{Hb}$ buffering), the Bohr-Haldane effect (Bohr-Haldane), and buffering by plasma proteins (Plasma proteins). Right column in each pair, to what extent the base deficit was reflected in a reduced bicarbonate concentration at a constant $p \mathrm{CO}_{2}\left(\mathrm{HCO}_{3}\right.$, const. $\left.p \mathrm{CO}_{2}\right)$, by a reduced $p \mathrm{CO}_{2}$ $\left(\downarrow p \mathrm{CO}_{2}\right)$, by the calculated uptake of chloride in the red blood cells $\left(\mathrm{Cl}^{-}\right.$uptake), by buffering by plasma proteins (Plasma proteins), and finally the difference between the base deficit and the sum of the components above (Unexplained). The data are mean values of seven subjects who cycled at constant power for 2 min to exhaustion. The values are for arterial (a) and femoral-venous (fv) blood just after the cycling ( $0 \mathrm{~min})$ and $6 \mathrm{~min}$ after the exercise $(6 \mathrm{~min})$. The chloride concentration of the red blood cells and the effect of a reduced or increased $\mathrm{CO}_{2}$-pressure were calculated as explained in the method section; for femoral-venous blood with a raised $\mathrm{CO}_{2}$-pressure this component came out negative. Base deficit and its components were calculated as explained elsewhere [24].

In arterial blood haemoglobin neutralised 33\% of the hydrogen ions, but the Bohr-Haldane effect was minimal. In femoral-venous blood haemoglobin neutralised $76 \%(0 \mathrm{~min} \mathrm{fv})$ and $45 \%$ of the acid load $(6 \mathrm{~min} \mathrm{fv})$. Those percentages include contributions by the Bohr-Haldane effect of $14 \%\left(2.3 \mathrm{mmol} \mathrm{L} \mathrm{L}^{-1}, 0 \mathrm{~min} \mathrm{fv}\right)$ and $4 \%$ $\left(0.7 \mathrm{mmol} \mathrm{L}^{-1}, 6 \mathrm{~min} \mathrm{fv}\right)$ of the total neutralisation . Thus, for femoral- 
venous blood just after the exercise the Bohr-Haldane effect neutralised more hydrogen ions that bicarbonate did.

For arterial blood the calculated chloride uptake in red blood cells was similar to the amount of hydrogen ions neutralised by haemoglobin; the small mismatch seen are well within the analytical errors. For femoral-venous blood there was an apparently unexplained component of $3.4 \mathrm{mmol} \mathrm{L}^{-1}(0 \mathrm{~min} \mathrm{fv})$ and $2.3 \mathrm{mmol} \mathrm{L}^{-1}(6 \mathrm{~min} \mathrm{fv})$. The chloride concentration of the red blood cells was in this study calculated, using equation [3] worked out for fully oxygenated blood and thus disregarding the Bohr-Haldane effect. If hydrogen ions neutralised by the Bohr-Haldane effect is included, the apparent mismatch is largely within the error of analysis and estimation.

Neutralisation by plasma proteins accounted for $10 \%$ of the base deficit in femoral-venous blood just after the exercise and 5-6\% in the other samples shown.

\section{CONCLUSION}

Bicarbonate neutralised most of the acids added to the blood, and haemoglobin neutralised most of the remaining part. Base deficit did not differ between arterial and femoral-venous blood with the same lactate concentration. The acid-base status of femoral-venous and arterial blood differed because of different degrees of respiratory acidosis or compensation. The chloride concentration of red blood cells rose in proportion to the amount of hydrogen ions buffered by haemoglobin.

\section{ACKNOWLEDGMENTS}

We are grateful to Astrid Bolling, Ada Ingvaldsen, Gunnhild Sand, Bjørg Ingrid Selberg, and Jorid Thrane Stuenæs for their skilled technical assistance.

\section{REFERENCES}

1. Adrogue H. J., Brensilver J., Madias N. E. (1978) Changes in the plasma anion gap during chronic metabolic acid-base disturbances. Am. J. Physiol. 235: F291-F297. 
2. Barbee R. W., Stainsby W. N., Chirtel S. J. (1983) Dynamics of $\mathrm{O}_{2}$, $\mathrm{CO}_{2}$, lactate, and acid exchange during contractions and recovery. J. Appl. Physiol. 54: 1687-1692.

3. Böning D., Klarholz C., Himmelsbach B., Hutler M., Maassen N. (2007) Causes of differences in exercise-induced changes of base excess and blood lactate. Eur. J. Appl. Physiol. 99: 163-171.

4. Bouhuys A., Pool J., Binkhorst R. A., van Leeuwen P. (1966) Metabolic acidosis of exercise in healthy males. J. Appl. Physiol. 21: 1040-1046.

5. Brace R. A. (1977) Fitting straight lines to experimental data. Am. J. Physiol. 233: R94-R99.

6. Dell R. B., Winters R. W. (1970) A model for the in vivo $\mathrm{CO}_{2}$ equilibration curve. Am. J. Physiol. 219: 37-44.

7. Fridericia L. S. (1920) Exchange of chloride ions and of carbon dioxide between blood corpuscules and blood plasma. J. Biol. Chem. 42: 245-257.

8. Funder J., Wieth J. O. (1966) Chloride and hydrogen ions distribution between human red blood cells and plasma. Acta Physiol. Scand. 68: 234-245.

9. Funder J., Wieth J. O. (1966) Potassium, sodium, and water in normal human red blood cells. Scand. J. Clin. Lab. Invest. 18: 167-180.

10. Funder J., Wieth J. O. (1967) Trapping of sodium, potassium, sucrose, and albumin in the packed cell column of the hematocrit. Acta Physiol. Scand. 71: 105-112.

11. Garby L., Vuille J. C. (1961) The amount of trapped plasma in a high speed micro-capillary hematocrit centrifuge. Scand. J. Clin. Lab. Invest. 13: 642-645.

12. Hamburger H. J. (1891) Ueber den Einfluss det Atmung auf die Permeabilität der Blutkörperchen. Z. Biol. 28: 405-416.

13. Hermansen L., Osnes J. B. (1972) Blood and muscle pH after maximal exercise in man. J. Appl. Physiol. 32: 304-308.

14. Hermansen L., Vaage O. (1977) Lactate disappearance and glycogen synthesis in human muscle after maximal exercise. Am. J. Physiol. 233: E422-E429.

15. Jacobs M. H., Stewart D. R. (1942) The role of carbonic anhydrase in certain ionic exchanges involving the erythrocyte. J. Gen. Physiol. 25: $539-552$.

16. Jones N. L. (2008) An obsession with $\mathrm{CO}_{2}$. Appl. Physiol. Nutr. Metab. 33: 641-650.

17. Juel C. (1988) Intracellular pH recovery and lactate efflux in mouse soleus muscles stimulated in vitro: the involvement of sodium/proton exchange and a lactate carrier. Acta Physiol. Scand. 132: 363-371. 
18. Kincaid D., Cheney W. (1996) Numerical Analysis. Brooks/Cole, Pacific Grove, CA, USA. p. 574.

19. Klocke R. A. (1976) Rate of bicarbonate-chloride exchange in human red cells at 37 degrees C. J. Appl. Physiol. 40: 707-714.

20. Krogh A. (1913) A bicycle ergometer and respiration apparatus for the experimental study of muscular work. Scand. Arch. Physiol. 30: 375-394.

21. Lazdunski M., Frelin C., Vigne P. (1985) The sodium/hydrogen exchange system in cardiac cells: its biochemical and pharmacological properties and its role in regulating internal concentrations of sodium and internal pH. J. Mol. Cell. Cardiol. 17: 1029-1042.

22. Lindinger M. I., Heigenhauser G. J., McKelvie R. S., Jones N. L. (1992) Blood ion regulation during repeated maximal exercise and recovery in humans. Am. J. Physiol. 262: R126-R136.

23. McKelvie R. S., Lindinger M. I., Heigenhauser G. J., Jones N. L. (1991) Contribution of erythrocytes to the control of the electrolyte changes of exercise. Can. J. Physiol. Pharmacol. 69: 984-993.

24. Medbø J. I., Hanem S., Noddeland H., Jebens E. (2000) Arteriovenous differences of blood acid-base status and plasma sodium caused by intense bicycling. Acta Physiol. Scand. 168: 311-326.

25. Medbø J. I., Mamen A., Olsen O. H., Evertsen F. (2000) Examination of four different instruments for measuring blood lactate concentration. Scand. J. Clin. Lab Invest. 60: 367-380.

26. Medbø J. I., Mohn A. C., Tabata I., Bahr R., Vaage O., Sejersted O. M. (1988) Anaerobic capacity determined by maximal accumulated $\mathrm{O}_{2}$ deficit. J. Appl. Physiol. 64: 50-60.

27. Medbø J. I., Sejersted O. M. (1985) Acid-base and electrolyte balance after exhausting exercise in endurance-trained and sprint-trained subjects. Acta Physiol. Scand. 125: 97-109.

28. Medbø J. I., Sejersted O. M. (1990) Plasma potassium changes with high intensity exercise. J. Physiol. 421: 105-122.

29. Medbø J. I., Tabata I. (1993) Anaerobic energy release in working muscle during $30 \mathrm{~s}$ to $3 \mathrm{~min}$ of exhausting bicycling. J. Appl. Physiol. 75: $1654-1660$.

30. Medbø J. I., Toska K. (2001) Lactate release, concentration in blood, and apparent distribution volume after intense bicycling. Jpn. J. Physiol. 51: 303-312.

31. Meloun B., Moravek L., Kostka V. (1975) Complete amino acid sequence of human serum albumin. FEBS Lett. 58: 134-137.

32. Nasse H. (1879) Untersuchungen über den Austritt und Eintritt von Stoffen (Transsudation und Diffusion) durch die Wand der Haargefässe. Pflugers Arch. 16: 604-634. 
33. Osnes J. B., Hermansen L. (1972) Acid-base balance after maximal exercise of short duration. J. Appl. Physiol. 32: 59-63.

34. Passoneau J. V., Lowry H. O. (1993) Enzymatic Analysis. Humana press, Totowa, NJ. Pp. 5, 188-193.

35. Riggs D. S., Guarnieri J. A., Addelman S. (1978) Fitting straight lines when both variables are subject to error. Life Sci. 22: 1305-1360.

36. Sahlin K., Alvestrand A., Brandt R., Hultman E. (1978) Acid-base balance in blood during exhaustive bicycle exercise and the following recovery period. Acta Physiol. Scand. 104: 370-372.

37. Sahlin K., Alvestrand A., Brandt R., Hultman E. (1978) Intracellular $\mathrm{pH}$ and bicarbonate concentration in human muscle during recovery from exercise. J. Appl. Physiol. 45: 474-480.

38. Sahlin K., Harris R. C., Nylind B., Hultman E. (1976) Lactate content and $\mathrm{pH}$ in muscle obtained after dynamic exercise. Pflugers Arch. 367: 143-149.

39. Siggaard-Andersen O. (ed.). 1976 The Acid-Base Status of the Blood. Munksgaard, København. Pp. 1-229.

40. Taylor H. L., Buskirk E., Henschel A. (1955) Maximal oxygen intake as an objective measure of cardio-respiratory performance. J. Appl. Physiol. 8: 73-80.

41. Tissot J. (1904) Nouvelle méthode de mesure et d'inscription du débit et des mouvements respiratoires de l'homme et des animaux. J. Physiol. et Phathol. Gen. 6: 688-700.

42. Tosteson D. C. (1959) Halide transport in red blood cells. Acta Physiol. Scand. 46: 19-41.

43. Turrell E. S., Robinson S. (1942) The acid-base equilibrium of the blood in exercise. Am. J. Physiol. 137: 742-745.

\section{Correspondence to:}

Jon Ingulf Medbø

National Institute of Occupational Health

POB 8149 dep.

NO-0033-8149 Oslo

Norway

E-mail: Jon.Medbo@stami.no 